\title{
Victor Gruen: the environmental heart
}

Leonardo Zuccaro Marchi

TU Delft, The Netherlands

Department of Architecture

L.ZuccaroMarchi@tudelft.nl

\begin{abstract}
Victor Gruen is the pioneer of the regional shopping centre, he is the "Mall Maker", which, is also the title of a book by $M$. Jeffrey Hartwick about this Austrian-born architect. Well known for his first commercial projects, which have been copied and analysed worldwide, mostly negatively influencing the structure of cities and societies, Gruen had focused his attention on the importance of the environmental crisis in his both theoretical writings and projects as early as the 1960s. How can Gruen be personified as both the "Mall Maker" and the "Architect of the Environment'? In the early 1970s Gruen presented Die Charta von Wien, as an attempt to readapt the CIAM's Charte d'Athenes to the contemporary conditions, with a brand new emphasis on the ecological environment as well. This paper will deal mainly with these contradictions and synergies between "consumeristic" architecture and its role in the city in relation to the environmental issues posed by its inventor. The complexity of the connections between consumerism and ecology and the references to CIAM and Gruen, appear to be important themes for a discussion on public space and our contemporary urban condition.
\end{abstract}

Keywords: Gruen; CIAM; commercial; environment; public sphere.

To cite this article:

Zuccaro Marchi, L.. (2017). Victor Gruen: the environmental heart. The Journal of Public Space, 2(2), 75-84. DOI: 10.5204/jps.v2i2.94

This article has been peer-reviewed and accepted for publication in The Journal of Public Space.

Please see the Editorial Policies under the 'About' section of the journal website for further information. 


\section{Victor Gruen}

Victor Gruen (Victor Grünbaum, Vienna, 1903 - 1980) was an architect born and professionally trained in Vienna. Here Gruen worked in an architecture office and in cabaret shows until 1938, when he emigrated with his wife to the US to escape Nazism. In the US, Gruen soon began to experiment and hybridise multiple roles within his architectural profession, exploring the dynamics of the interaction between private commercial spaces and public spaces, between the design interest and the theoretical interest and between the cabaret-musical character and the architectural process, from both the perspectives of architectural scale and urban scale. More interestingly, he developed a crucial interest in research and design surrounding environmental issues, modernist references and commercial design.

The complexity of Gruen's work, a man who is considered to be the pioneer of the regional shopping centre or the "Mall maker" (Hardwick, 2004), is certainly of great interest for a contemporary discussion on the public sphere. This is clearly evident if we consider, for instance, the profound contradiction between, on the one hand, the lacuna in most academic history books which hardly mention Gruen's name and, on the other, the real influence of his work on the development of commercial types in architecture and, more broadly, even on the structure of cities throughout the world.

Indeed, if in the early 1990s Margaret Crawford claimed that "the world of the shopping mall [...] has become the world" (Crawford, 1992, p. 30), then Gruen is certainly one of the main people responsible for this change regarding the commercial evolution of the public sphere and their contradictory relationship. This friction seems even stronger today, since the contemporary crisis of the consumerist economy, which has affected the built environment as a whole and, as a consequence, many examples of the degenerate, parasitical evolution of Gruen's architecture have turned into zombie-like dead malls. Therefore, faced with this contemporary condition, it is worthwhile to re-examine, rediscover, reconsider and reinterpret the original design and theoretical work of the Shopping Centre pioneer, who remarkably foresaw many issues in our contemporary debate, such as the environment, beyond the mere commercial-consumerist-capitalist strategy.

Since his first proposal in the early 1950s, Gruen's commercial projects were imbued with an ethical attention to environmental and social issues. In his own words, all his commercial projects were conceived not only as mere consumerist machines, but as "urban crystallisation points" (Gruen, 1973, p. IX), which could on the one hand

"offer to the suburban population significant life experiences"(Gruen, 1973, p. IX)

and on the other

"create environmental qualities that will help fulfil the human heart's desire in the city's heart.” (Gruen, 1973, p. 299)

The Regional Shopping Centre was Gruen's first attempt to generate urban crystallisations in the suburbs. It represented a new architectural archetype, germinating outside the traditional core with the idealistic intention of attracting and polarising the dispersed community. 
This mix of consumerism and urban structure went from being an architectural expression to a real urban proposal, firstly with the renewal of existing city centres, such as Fort Worth. "Downtown Needs a Lesson From the Suburbs" (Gruen, Business Week, 1955 ) is the general expression of the redesigning of US downtowns through the shopping centre experience.

However, at the same time Gruen also considered the possibility for a complete transformation of his architectural experiment into a newly founded urban centre.

If the lack of social and physical connections with the surrounding urban context partially caused the failure of and the main criticisms of the Shopping Centre, usually enclosed within a huge anonymous parking belt, then the context itself turned into the main topic of the project. The Architectural crystallisation point was scaled up into a broader urban crystal. The Regional Shopping Centre became an integrated part of Gruen's urban model, together with its residential units, where both the commercial design devices and the environmental-humanistic values were re-interpreted.

\section{Vienna as paradigm}

If Gruen adopted the medieval market as a main reference for the pedestrian cluster evolution of the shopping centre, then the medieval European urban centre became the main influence for new urban projects.

In particular, his city of origin, Vienna, Europe's "centre of intellectual and cultural life" (Gruen, 1973, p.I73), embodied Gruen's professional link with European modern architecture and his personal affection for the European historical city. For Gruen it represented a sentimental synthesis of architectural schooling and traditionalist urban origins. This became evident, for instance, when Gruen metaphorically transplanted Vienna to the USA, as the main reference for his American Fort Worth project, shown at the First Urban Design Conference at Harvard in 1956.

Vienna was indeed the main paradigm for attaining the right compactness and the right distinction between 'Cityscape', as "a setting where man-made structures are predominant", and 'Landscape', as "an environment in which nature is predominant [...]; the successful marriage of nature and human endeavour" (Gruen, 1955), which was very much lacking in sprawling North American cities.

The limited size and the enclosed medieval structure of Vienna was re-interpreted by the Austrian-born architect as a correct frame and design for contemporary inner cities, whose human scale and life was in danger from the assault of vehicular traffic, under the "invasion of mechanical hordes" (Gruen, 1964, p. 214). Indeed Vienna's concentric historical defensive walls, which saved the city and Europe itself from the invasion by the Turks in the $17^{\text {th }}$ Century, became a first inspiration in Fort Worth: Gruen designed a system of concentric rings of highways whose purpose was to gradually filter and limit the access of cars to the centre, preserving the central pedestrian nucleus. ' Hence the historical urban reference was not merely an ideal urban metaphor used as a discursive counterforce to the "process of constant and unchecked decentralisation and land speculation [...]", which are "[...] a real menace to all our cities and to the stability of civic values," as Sert affirmed (I952, p. 3). It was a concrete physical model able to re-adapt, re-interpret and hybridise with new contemporary urban infrastructures, in the brand-new urban context of the "Shopping Town USA" (Gruen, Smith, 1960). 
However, in contrast to Vienna, the Fort Worth project was conceived on an artificial platform. Besides the defence system, the separation between cars and pedestrians was also guaranteed by a podium, a new artificial pedestrian ground level inside the inner pedestrian ring, which separated the underground goods delivery space, parking garages and the cluster of new buildings above.

Interestingly and contradictorily, on the one hand in Fort Worth the traditional city was the main reference for a return to a new human environment. On the other, Fort Worth became the "first of the business-districts-on-a-podium" according to Banham (1976, 42), a huge brand new megastructure, an over-scaled element representing the total artificiality of both the natural level and the "milieu humain"2 (Lefèbvre, 2003, p. I7) itself.

Besides this ambivalent urban-social condition, Gruen's humanising-crystallisation process and split between car and pedestrian flows echoed the importance of the right of the pedestrian, "la royauté du piéton" as praised by Le Corbusier. This was an outstanding characteristic of the Core asserted during the eighth edition of CIAM (International Congresses of Modern Architecture). In the final "Summary of needs at the Core," the book published on CIAM 8, we find points 3 and 4:

" 3 - That the Core should be a place secure from traffic - where the pedestrian can move about freely.

4 - That cars should arrive and park on the periphery of the Core, but not cross it"

(Tyrwhitt, Sert, Rogers, 1952, p. 64).

Moreover, at CIAM 8 the split between pedestrian and vehicular flows also raised a symbolical value, between the heart as a humanist symbol "which springs directly to the senses without explanation" (Giedion, 1952, p. 17), and the "mechanized killing” (Giedion, 1958, p. 35), the "tyranny of mechanical tools" (Giedion, 1952, p. 17) which led to the destruction of War.

Gruen seemed to carry this legacy of CIAM 8, stressing this symbolical humanising process inside the city. This was first experimented and tested on the architectural scale of the shopping centre, such as at the Northland Shopping Centre, near Detroit, designed in 1954: the first modern pedestrian commercial centre with a 'merchant city' form, composed of a cluster plan, where the pedestrian space was the introverted void formed inside the composition of the full shopping volumes. Another important example of Gruen's commercial designs was the Southdale Centre which became the first shopping centre with air conditioning, where the topic of the human scale was melded with the artificial climate as a commercial strategy.

On the one hand, the CIAM 8 even became a "reference point for the new forms of public space, including Shopping malls [...]", as Mumford affirms (2000, p. 2I5). On the other, the new forms of commercial space fascinated CIAM members Sert and Tyrwhitt, who described these shopping centres as

"an idea of what these new urban cores might be like [...] our open expression of the new humanising trend in the urban scene" (Sert, Tyrwhitt, 196I, p. 106).

Remarkably, CIAM's references soon became hybridised with Vienna itself. The relationship with his native city became so strong that in the late 1960s, Gruen decided to retire from his firm in Los Angeles, Victor Gruen Associates, and move back to his old 
central district in the Austrian capital. There he opened another architectural firm, Victor Gruen International, which was characterised by project attitudes that differed from those implemented at the US firm, which was based and founded on shopping centre design.

In the same period, Gruen recognised the general American perversion and bastardisation - still present nowadays - of his original shopping centre idea, represented by thousands of new banal reproductions spread around the US. "I refuse to pay alimony for those bastard developments" (Hardwick, 2004, 216 ), Gruen affirmed in 1978. His original and idealistic concept of a mix between commercial and humanistic values, between functional and urban themes has been adsorbed only in its purely economic character. The failure of Gruen's purpose for the shopping centre was evident when, as described by Hardwick, the mall maker himself started to fight against the construction of a shopping centre outside Vienna, which would have sucked all the commercial attractions out of the city. ${ }^{3}$ The "Irresistible Empire" (de Grazia, 2006) of consumerism was infiltrating his old Europe more and more. In a certain sense, it was his own invention which turned against him, destroying the life of his beloved native city.

Faced with this failure, in the early 1970s Gruen proposed a project for Vienna which was similar to that at Fort Worth. It envisaged an external ring of viability and fingers of parking garages, hosting approximately 20,000 cars, inserted in the pedestrian Core. The scheme was proposed as the only way to save his beloved city from its traffic problem. On the other hand, in Vienna he concentrated his theoretical and design activity on a particular theme of his "The heart of our cities" (Gruen, 1964): the environmental issue.

\section{The Vienna Charter}

In 1970 Gruen founded the Victor Gruen Foundation for Environmental Planning, while his beloved Vienna even became the main reference for his new manifesto for architecture, centred on the ecological theme: "Die Charta von Wien" (The Vienna Charter) (Victor Gruen Foundation for Environmental Planning, 1973).

The direct reference to CIAM itself, in particular to the Athens Charter, written by the CIAM founders in 1933, was finally and clearly stated. The CIAM's charter was not a mere reference, but a cohesive portion of the new charter, due to its highly influential insight and the fact that it had already proposed outstanding, widely accepted principles. For instance, the $76^{\text {th }}$ paragraph concentrated on the right shape of the human environment, which should be highlighted again within the new manifesto of environmental planning: "Le dimensionnement de toutes choses dans le dispositif urbain ne peut être régi que par I' échelle humaine” (CIAM France, 1943, chap. 76).

However, at the same time, Gruen stressed the need to rethink and update the Athens Charter to contemporary conditions and requirements, which have both changed profoundly over the last forty years. The Charter had been a powerful means of both urban transformation and professional training for many architects and this had led to the diminution of construction density and to the separation of urban functions. However, these principles had been vehemently asserted and highlighted during the 1930s when their validity was still intact. Unfortunately, their myopic application, without considering the new urban conditions, caused urban decay and the division of the city into "monofunctional ghettos" (Victor Gruen Foundation for Environmental Planning, 1973). Moreover, 
the Athens Charter was proposed on the analysis of thirty-three cities (twenty-eight in Europe, three in the USA and two in Asia), while Gruen reminds us that in the 1970s there were 131 megacities across the world (38 in Europe, 35 in Central-North America, 10 in South America, 42 in Asia, 4 in Africa and 2 in Australia) and it was no longer possible to ignore the diversity and complexity of all of them. ${ }^{4}$ Furthermore, he stressed that $16-18 \%$ of the total world population lived in urbanised districts: it meant that cities, even in a crisis, were (and are) still attractive destinations.

These new conditions and issues were also described in his book "Centers for the Urban Environment. Survival of the City," published in the same period as the Charter, in 1973. The book

"represents an expression of the effort of the Foundation to bring about a greater public understanding of the decisive role which "Environmental Planning" should and must play if the ecological and biological balance of our planet, which is essential for the continuous existence of the human species, is to be assured." (Gruen, 1973, p. V).

Similarly to the Charter, the "Center of urban Environment" is centred on both the human and environmental issues in the city. This charter exactly mirrors the honours bestowed on the founder of the Foundation. Indeed Gruen proudly reminded the reader in the introduction that he had been officially recognised as both "Architect of the People", during his presentation at Rice University, and "Architect of the Environment" (Gruen, 1973 p. $X)$ in an article in Fortune Magazine.

Furthermore, both the book and the charter represented a continuity with CIAM's statements, in particular with the Heart of the City. In fact the efforts made towards securing the humanising process inside the city, were the same at CIAM 8 as in Gruen's writings. As Alex Wall affirms

"[...] the link between Gruen`s own thinking and the CIAM debates on the city, was probably CIAM 8's 1952 book The Heart of the City” (Wall, 2005, p. 227).

The brand new element introduced by Gruen was the emphasis on the ecological environment, as a rising necessary theme, in the early 1970s, in addition to the preservation of human values.

We can therefore consider Gruen's environmental interest as an updating, or translation to his contemporary context, of those humanistic purposes expressed for instance by Giedion, quoting the humanism and existentialism of Sartre. Indeed the mechanical tools "which take commands" (Giedion, 1948) and the excess of trust on progress were considered by Gruen as the same enemies for both environmental and human entities. Moreover, the environmental aspect was already subtly present in some of the discourses at CIAM 8 too. For instance, Gregor Paulsson drew connections between Habitat, Ecology and Heart of the City during his speech "The past and the Present" (Paulsson, 1952, p. 28), in Hoddesdon. But the 1950s was too soon for CIAM members to recognise environmental sustainability as a key theme for planning. It was difficult for Gruen himself to introduce it as the basis of planning 20 years later, as Alex Wall affirms

"when the threat to the environment was neither widely accepted nor understood." (Wall, 2005, p. 23I) 
Indeed the UN's first major conference on international environmental issues (United Nations Conference on the Human Environment), held in Stockholm in 1972, was coeval with the Vienna Charter.

As far as the latter is specifically concerned, the principle theses are listed and summarised in four points in the first part:

"A. Man stays at the medium point of each urban planning and architecture.

B. The first aim of both urban planning and architecture must be therefore the satisfaction of both human needs and human hopes.

C. The conquests of Science and Technology must be used in order to satisfy the main aim: the greater satisfaction of Human life.

$D$. It is necessary not to allow Science and Technology to become mere purposes. Indeed they can neither tyrannize nor liquidate the Humanity." (Victor Gruen F. E.P., 1973)

The Charter then continues with six other short chapters explaining these principles. The second one concerns the ecological theme and is indeed entitled 'The global environmental crisis': Gruen focused his attention on the problem of the battle between Man and Nature, hoping that the first will never win. A way to survive would be to transport the hierarchy of values from "increase and quantity" to "humanism and quality" (Victor Gruen F.E.P., 1973), in a new organic approach to planning.

The urban proposal for a foundation of a new Cellular Metropolis, a scheme for a new Urban Pattern presented by Gruen, would be his attempt to consider the city as an organic structure in continuity with a living organism, keeping humanity as the first qualitative element for planning.

The third and fourth chapters entitled 'The needs and hopes of Man' and 'The essence of urbanity', defined urbanity as the place of total 'personal freedom', where everyone is free to choose where to work, where to live, where to exchange ideas etc. As fundamental conditions he listed:

I- compactness

2- maximum integration of human functions

3- maximum separation between mechanical-service functions and human functions. The essence of urbanity, sometimes called the essence of urbia, was nothing more than

"the Core of the city, which I shall call its 'heart"” (Gruen, 1964, p. 12)

as he mentioned some years before in his book 'The heart of our cities'. Therefore, the Heart of the City was an integrated part of the new rising human-environmental theme. The three conditions were also the same as the CIAM 8 discourses but with differences. In particular, the aim of centralisation and compactness of the urban structure shifted from the survey of civic values (Sert) to the rescue of the environment (Gruen). The fifth and sixth chapters deal with the 'Bureaucracy of the Project' and 'The essence of the Architecture'. Gruen denounced the fact that cultural urban principles, which were dictated by the master architects of the 1930s for their present conditions, have been translated anachronistically into laws, rules and urban regulations in a totally transformed contemporary society. For instance, zoning, which was originally conceived in order to control the dispersion of industrial zone development, negatively transmuted the city, changing "the urban organism into ghetto-like enclaves" (Victor Gruen F. E.P., 1973). The 
latter were the opposite expression of the "multifunctional" Heart, which was sustained by the integration of different urban services and functions in a three-dimensional design. In this scenario, the architect passively witnessed the metamorphosis of his profession from the original Greek profession of 'Architekton', the master of construction, to a mere 'décorateur de façades'. Only the recognition of the urban and environmental crisis could finally enhance the Role of the Architect in her "all human society," as Gruen affirmed. Finally, in the last chapter 'New opportunities, ways and paths', Gruen attacked traffic specialists, whose work was causing the augmentation of traffic volume and speed and the consequent laceration of the city structure. The Athens Charter, Gruen stated, had already foreseen that traffic would cause total chaos in cities, even when there were very few cars in comparison with his own contemporary situation. Moreover, traffic was another theme already explained and criticised before in "The heart of our cities", where Gruen considered its excess as the main disease infecting the proper blood circulation system towards the pumping heart. Traffic was a counterforce, an enemy in front of the complexity of the Heart of the City, considered as both a humanist-environmental symbol and functionalist-mechanical metaphor.

\section{Conclusion}

In conclusion, the humanising process of CIAM 8's Heart of the City became a main reference for both the theoretical and design work of Gruen, who hybridised it with his personal research on commercial design and with the mounting interest in the environmental issue.

Moreover, in the 1960s Gruen re-interpreted the CIAM 8 theme, the Heart of the City, when he applied it to his shopping design experience in the North American context; while, in the early 1970s, he used the Heart issues to re-envision and resume CIAM itself. Indeed the environmental interpretation of the Heart of the City allowed Gruen to reinterpret all CIAM's principles many years after its decline. In particular for Gruen, the first theoretical expression of CIAM, the Athens Charter, was still a valid and contemporary tool rather than an obsolete and dangerous vision of the city, as it was considered by Team I0. Fifteen years later, at CIAM's end in Dubrovnik at the hands of young Team 10 members, Gruen detected a possible legacy of the Modern Movement. Its basilar principles were recognised by the 'Mall Maker' as tools that were still useful for contemporary and future environmental discourse, which needed only to be constantly updated in line with mutable urban-social conditions in order to reaffirm their validity. Interestingly, Gruen's shopping centre design experience became his first link with the Modern Movement and its idea of the humanising core. This connection was then developed through urban projects, transatlantic encounters and flows of ideas, and urban references, culminating in a reinterpretation in Vienna of the most intense manifesto of CIAM.

Finally, Gruen reconsidered the Athens Charter within his coeval new urban-social conditions, through his personal commercial-urban design experience, and the Charter remains a worthwhile contemporary reference in order to tackle our contemporary built environment, when, for the first time ever, the majority of the world's population lives in cities. It is no coincidence that after Gruen, other Athens Charters have been proposed at the last UN Habitat conference in 2016, pivotal thinkers such as Richard Sennett and 
Saskia Sassen emphasised the need for an updated Athens Charter, the original of which still affects our lives in the built environment.

\section{Notes}

(I) Indeed, the inner ring is the impenetrable wall, inside which only pedestrian or public vehicles are allowed to enter. Motorists, coming from the metropolitan region, have to leave their automobiles inside the car parks. These multilevel parking terminals are thought to have space for 60,000 cars in total; they are organised over various levels and extend from the ring-road towards the inside, "penetrating like fingers" into the central zones. Gruen's team estimated that it would take 2-4 minutes on foot, to reach the pedestrian areas from the car parks.

(2) "De Metropolis de Fritz Lang au Cinquième Élément de Luc Besson, en passant par Blade Runner de Ridley Scott, I'artificialisation du milieu humain conduit a la catastrophe." (Lefèbvre, 2003, p. I7)

(3) "American cities, with their comparatively short histories and small traditions [...] offered people little beyond traffic jams.[...] for Europe the thoughtless copying of the American shopping centre has been truly catastrophic." (Hardwick, 2004, p. 217-219).

(4) "In den I3 I Millionenstädten der Welt leben zur Zeit 320 Millionen Menschen. [...] Von den I I Millionenstädten der Erde liegen 38 in Europa, 35 in Nord- und Zentralamerika, 10 in Sùdamerika, 42 in Asien, 4 in Afrika und 2 in Australien " Victor Gruen Foundation for Environmental Planning, 1973).

\section{References}

Banham, R. (1976). Megastructure. Urban Futures of the recent Past. London: Thames and Hudson. CIAM France, Le Corbusier (1943). La Charte d'Athènes. Paris: Plon.

Crawford, M. (1992), The World in a Shopping Mall. In M. Sorkin (Ed.), Variations on a theme park. The American city and the end of the public space. New York: Hill and Wang.

De Grazia, V. (2006), Irresistible Empire: America's Advance through Twentieth-Century Europe, USA: Belknap Press.

Giedion, S. (1948), Mechanization takes Command. New York: Oxford University Press.

Giedion, S. (1952), Historical Background to the Core. In Rogers, E.N., \& Sert, J.L., \& Tyrwhitt, J.,(Eds.), The Heart of the City - towards the humanisation of urban life. New York: Pellegrini and Cudahy.

Giedion, S. (1948), Architecture You and Me. Cambridge, MA: Harvard University Press.

Gruen, V. (1955, September), Cityscape and Landscape. Arts and Architecture, 18-37.

Gruen, V. (1955, October 22), Downtown Needs a Lesson From the Suburbs, Business Week, 6466.

Gruen, V. (1964), The Heart of Our Cities - The Urban Crisis Diagnosis and Cure. London: Thames and Hudson.

Gruen, V. (1973), Centres for the Urban Environment. Survival of the Cities. New York: V.N.R. Company.

Victor Gruen Foundation for Environmental Planning (1973), Die Charta von Wien. Zentren als urbane Brennpunkte from Tu Wien Library, 260IG, 44 I.540 I. Library of Congress, Washington. Victor Gruen Papers: Box 48, Folder 5.

Hardwick, M.J. (2004), Mall Maker. Victor Gruen, Architect of an American Dream. Philadelphia: University of Pennsylvenia Press.

Lefèbvre, V. (2003), Paris - Ville moderne : Maine-Montparnasse et La Défense 1950-1975. Paris: Norma.

Mumford, E. (2000), The CIAM Discourse on Urbanism, 1928-1960. Cambridge, MA: The MIT Press. 
Victor Gruen: the environmental heart

Paulsson, G. (1952), The Past and the Present. In Rogers, E.N., \& Sert, J.L., \& Tyrwhitt, J.,(Eds.), The Heart of the City - towards the humanisation of urban life. New York: Pellegrini and Cudahy. Rogers, E.N., \& Sert, J.L., \& Tyrwhitt, J.,(Eds.). (1952) The Heart of the City: towards the humanization of urban life. New York: Pellegrini and Cudahy.

Sert, J.L.(1952), Centres on Community Life. In Rogers, E.N., \& Sert, J.L., \& Tyrwhitt, J.,(Eds.), The Heart of the City - towards the humanisation of urban life. New York: Pellegrini and Cudahy.

Sert, J.L., Tyrwhitt, J. (196I), The Shape of the American City. In Contemporary Architecture of the World, Tokyo: Shokokusha. Quoted in Mumford, E. (2009), Defining Urban Design - CIAM Architects and the Formation of a Discipline, 1937-69. (p. 144), New Haven and London: Yale University Press.

Wall, A. (2005), Victor Gruen - From Urban Shop to New City. Barcellona: Actar.

84 | The Journal of Public Space, 2(2), 2017| ISSN 2206-9658

(c) Queensland University of Technology 